\title{
Hobbes's Thucydides and the Colonial Law of Nations
}

This article attempts to make sense of Thomas Hobbes's 1628 translation of Thucydides, published as Eight Bookes of the Peloponesian Warres, in terms of seventeenth-century interest in and debates over the law of nations, or ius gentium. Its aim is to shift the scholarly focus on Hobbes's translation from its most often assumed context, that of royalism, to what I will argue is a more fitting context, that of the law of nations, and by extension, the intellectual history of international law. Among Hobbes scholars, the fact that the first publication to which Hobbes gave his name was a classical translation is often noted but rarely considered in much depth. ${ }^{1}$ For many years, orthodoxy held that Hobbes started his brilliant philosophical career with a humanistic period before he encountered the Euclidean geometry that would occasion his turn from humanism to 'political science' - a turn variously construed as virtue to vice or vice to virtue, depending on the critic. Recent scholarship has rightly questioned such narratives, noting for instance that Hobbes late in his life wrote a verse autobiography and an anticlerical poem in Latin and translated Homer from the Greek. The insistence that Hobbes's humanism persisted throughout his lifetime, however, does not fully account for the Thucydides translation: acknowledging Hobbes the humanist only spawns further questions. ${ }^{2}$ Now that Hobbes's Thucydides translation is seen less and less as something from which Hobbes would later turn, questions of what sort of project was signalled by the Thucydides translation come to the fore. Recent work by Jeffrey Collins and Kinch Hoekstra, taking aim, on the one hand, at the story of Hobbes's purportedly consistent royalism, and, on the other, at Hobbes's supposed turn to de facto-ism in Leviathan (it turns out it was there all the time), has made interpreting Hobbes's intentions with the Thucydides volume all the more significant. ${ }^{3}$ In this vein, a number of diachronically conceived studies have linked Thucydides and Hobbes's later work, Leviathan in particular, yet they have often treated Hobbes's encounter with Thucydides as an inevitable communion of like political minds rather than as an encounter encouraged and surrounded by other texts and 
historical events. ${ }^{4}$ It remains an open question, in other words, why Hobbes chose to translate Thucydides in the first place. This article therefore takes a more synchronic approach and seeks to reconstruct the intellectual context in which Hobbes translated and then published his Thucydides, asking two interrelated questions: why Thucydides? And why 1628? Ultimately, I will argue, Hobbes's translation should be seen not just as a precursor to his later treatises but as part of broader attempt on the part of English humanists in the mid-1620s and early 1630s to make available to English readers the stories and exempla - the raw materials - necessary to underpin an ethical, English law of nations. Hobbes's Thucydides, it will be suggested, was vitally concerned with the law of nations and concerned particularly with the legal justifications and moral obligations of empire.

In making such an argument, this article will develop in three stages. First, identifying some limitations of existing literature on the context for Hobbes's Thucydides translation, I will propose that Hobbes's Thucydides should be seen not solely in terms of domestic English politics, but in more global terms that, while encompassing domestic English politics, also resonate out into England's growing empire. This section will briefly discuss Parliamentary politics in 1627-28, not for its own sake but for the wider purpose of dislodging some prevailing assumptions about Hobbes's intentions with the Thucydides volume. I will then turn to two theorists of the ius gentium, Alberico Gentili and Hugo Grotius, both of whose works could be found in the library Hobbes tended in the 1620s, to explore the unique demands the genre of the early modern Latin ius gentium tract made on ancient histories, which were seen to hold the potential to speak about the ius gentium by indicating the laws 'common to all known legal systems' and 'all known peoples. ${ }^{5}$ How exactly Hobbes conceived of the law of nations in 1628 is difficult to say. Later in his career, he sought to equate the law of nations with his pessimistic law of nature, although it is possible that he had not yet developed this equation when he translated Thucydides. ${ }^{6}$ What is certain though is that Thucydides took on a new importance as writers like Gentili and Grotius theorized the relation between the ius gentium and natural law. As Grotius put it in his 1625 De Jure Belli ac Pacis, theorists 'are mostly very muddled and confused about which laws are natural, which divine, which are part of the law of nations, which are civil laws, and which belong to the canon law. The great deficiency in all of these writers was that they lacked the illumination provided by History." De Jure Belli ac Pacis, which drew extensively from classical histories like Thucydides's Peloponnesian Wars, can be seen as underscoring for English humanists like Hobbes the need for a storehouse of exempla in English that could be marshalled in this new discourse of the ius gentium to guide Anglophone colonialists. Another influence can be found in literary history, however wont Hobbes might have been to deny it. According to Aubrey, 'Before Thucydides, [Hobbes] spent two years in reading romances and plays." While we have little sense of which romances 
and plays Hobbes read, Shakespeare's collaborative effort Pericles, Prince of Tyre, originally published in 1608 and then appearing in four more quartos by 1630 , provides a fascinating example of the type of thinking Thucydides could spark in Stuart England. Pericles deserves attention in this context for its own investigation of the law of nations. The final section will turn to book history to point out the proliferation of English translations of classical histories appearing in the mid-1620s and early 1630s from humanists interested in the law of nations.

\section{Rhetoric and Royalism: Thucydides and the Virginia Company}

To start, we should note the reasons that have previously been given for Hobbes's interest in Thucydides. This will require a brief descent into the gritty details of Stuart parliamentary politics. If they have approached the topic at all, most critics have seen Hobbes's translation in the context of his royalism. In this, they are following Hobbes himself. In an autobiographical poem first published in Latin in 1679, Hobbes wrote that of all the classics,

There's none that pleas'd me like Thucydides.

He says Democracy's a foolish thing,

Than a republic wiser is one king ${ }^{9}$

Hobbes comments similarly in his prefatory 'Life and History of Thucydides' that Thucydides 'least of all liked the democracy' and 'best approved of the regal government.' 10 Thus, with more than clear warrant, Miriam Reik, J. P. Sommerville, Jonathan Scott, and David Norbrook all see Hobbes as impugning the divisive and potentially seditious rhetoric surrounding the 1628 Parliament whose work culminated in the Petition of Right but which Hobbes would have seen, in the words of his 'Life of Thucydides', as the 'contention of the demagogues for reputation and glory of wit'. ${ }^{11}$ Only Norbrook, however, remarks upon the tension that would have accompanied such an arch-royalist position for Hobbes - a tension I wish to dwell upon in what follows in order to argue for a broader context for Hobbes's royalist comments.

The main problem can be summarized as follows: if the parliamentary agitators are indeed Hobbes's 'demagogues', then Hobbes's friend and recently deceased patron, William Cavendish, second Earl of Devonshire, would have to be counted a prime accessory to demagoguery. As Norbrook notes, Cavendish, whose secretary Hobbes proudly claimed to be on the title page of his Thucydides and whom Hobbes called in the dedicatory epistle 'one whom no man was able either to draw or [j]ustle out of the straight path of [J] ustice', had been sympathetic to the plight of the Five Knights imprisoned for their refusal to pay Charles's forced loan, a refusal that ultimately led to the Petition of Right. ${ }^{12}$ As late as November 1627, Cavendish was still 
refusing to pay the very loan the five knights had been in prison since July for resisting. ${ }^{13}$ Though Cavendish ultimately subscribed to the loan, paying by December and even using Hobbes himself to squeeze payments out of reluctant Derbyshire residents, he demonstrated his distaste for special royal measures in the subsequent Lords debates over the arbitrary imprisonment of the refusers. ${ }^{14}$

Cavendish's tepid opposition may come as a surprise to readers accustomed to a portrait of Cavendish as an obedient subject of the crown, whether on the loan or subsequent debates over imprisonment. ${ }^{15}$ Yet Cavendish was the prime devotee of the period's most demonstrably republican publication, Thomas May's 1627 translation of Lucan's Pharsalia, and parliamentary historians such as Richard Cust and Jess Flemion follow Cavendish's contemporaries like John Holles, first Earl of Clare, in associating Cavendish with those 'opposition peers' (Flemion's term) who were particularly peeved by the forced loan and who, in conference with the house of Commons in the spring of 1628, subsequently worked for a Petition of Right to protect against arbitrary imprisonment for so-called reasons of state. ${ }^{16}$ Cavendish's activities in the Lords debates over the Petition of Right were subtle, and therefore easy to misinterpret. He displayed nothing like the outspoken urgency of Bishop Williams of Lincoln or Viscount Saye and Sele, the latter of whom for example argued passionately, it is the due right of the subject not to be committed without cause expressed'. ${ }^{17}$ Rather, it appears that in a way similar to his response to the forced loan, Cavendish sought to resolve his objections against an overreaching crown, which was operating troublingly in the language of reason of state, and his obedience to his rightful monarch. ${ }^{18}$ On the one hand, Cavendish specifically argued that the king's prerogative was part of 'the law of the land', a statement that Sommerville suggests shows Cavendish's misgivings over the Petition. ${ }^{19}$ But such evidence must be balanced against Cavendish's speech against discretionary imprisonment in which, quoting Magna Carta, he argued that it was 'proved' that 'a free man ought not to be committed nisi per legem terrae'. ${ }^{20}$ The debate was fluid enough that Northampton bewailed at one point, 'I hear so many learned speeches that I am still of opinion with him that spoke last', but the tension in Cavendish's speeches need not be ascribed to excessive malleability. ${ }^{21}$ Flemion has shown that even vehemently pro-Petition figures like John Selden, in the House of Commons, and Viscount Saye in the Lords used the same argument Cavendish did - that the prerogative was 'tacit' - in order to keep an explicit statement of the king's prerogative out of the Petition's final wording. ${ }^{22}$ Statements like Cavendish's accepting the prerogative can therefore be found on all sides. That Cavendish's ultimate motivation for such a statement was keeping explicit mention of the prerogative out of the Petition can be seen from his speech on 22 April 1628, about a month after Hobbes's Thucydides was entered into the Stationers' Register and less than two months before Cavendish's death (20 June 1628). ${ }^{23}$ When inclusion of language watering 
down the Petition seemed imminent and Petition opponents were therefore calling for votes, Cavendish strategically intervened for further discussion with the Lower House, seeking 'a way to avoid disunion with the [staunchly pro-Petition] Commons'. ${ }^{24}$ Based on surviving diaries, it appears he never questioned the prerogative outright nor even spoke particularly regularly; instead, his main interests appear to have been process-oriented - 'avoid[ing] disunion', 'conferenc[ing] for accommodation'. ${ }^{25}$ Cavendish's language of accommodation unarguably had political bite, since the 'accommodation' with the Commons was accommodation with the strongest voices for the Petition, yet his particular emphasis on compromise shows evidence of a man eager to negotiate conflicts rather than to inflame them. We can discern from Cavendish's initial loan refusal and modest steps in favour of the Petition of Right that Cavendish imagined limits to royal authority, yet we can also see Cavendish's stoic reluctance to parade his disobedience or to countermand royal authority in too dramatic a fashion, if at all.

Cavendish's politics can give, at best, an imperfect picture of Hobbes's. Yet they do point us to a tension in the Thucydides volume that contemporary observers would have noted but that has yet to be adequately addressed - namely, the tension between Cavendish's strategically oppositional legacy and the voluble royalism of the Thucydides prefatory material. Appreciating the full measure of this tension requires reference to the Renaissance demands of rhetoric, in particular the way that those making political proposals (the domain of deliberative rhetoric) were counselled to use to use praise and blame (epideictic rhetoric) in pursuit of their ends. ${ }^{26}$ Positing Hobbes's specific ends, of course, presents considerable difficulties, but the endeavour is aided by considering a transatlantic context for Hobbes's work during this period. In a remarkable 1981 article (recently reprinted), Noel Malcolm demonstrated that, like Cavendish, Hobbes both held stock and participated in the dramatic internal wrangling of the Virginia Company, siding with the prominent faction of the longtime Stuart antagonist Sir Edwin Sandys..$^{27}$ But, as he notes, 'there are almost no indications of how Hobbes was occupied after the [resulting 1624] dissolution of the Company'. ${ }^{28}$ Most scholars have therefore assumed that the crown's revocation of the Virginia Company patent marked the end of Hobbes's financial and intellectual interest in the New World. There are nevertheless reasons to question this assumption. First, even after Charles took control of the Virginia Company, Cavendish remained deeply invested in the offshoot company active in the Bermudas, the Somers Island company - so invested, in fact, that the eminent historian of the New World companies W. F. Craven wrote that 'of all those leaders who fought so valiantly, and bitterly, by the side of Sandys in 1623-1624, only Lord William Cavendish was possibly more vitally concerned with the fortunes of the [the Bermudas] than [Virginia]. ${ }^{29}$ At Cavendish's death, the Governor of Bermuda, Roger Wood, wrote a consoling letter to Cavendish's widow that also gently reminded her of the Cavendishs' 'poor tenants' 
on their Bermuda land - still today the parish of Devonshire - who 'labour almost in nakedness' ${ }^{30}$

It bears repeating that the only known evidence of Hobbes's involvement with the Somers Island Company comes before Charles disbanded the Virginia Company. But given the Cavendishs' involvement lasting even through the Stuart Restoration, as well as the relative dearth of surviving documentary evidence, the possibility should not be dismissed. ${ }^{31}$ Though it has not, to my knowledge, been discussed in Hobbes scholarship, a more important factor is that even after the revocation of the Virginia Company charter (I shy from 'dissolution' for reasons that will become clear), many of the Sandys faction of Virginia adventurers harboured hopes, not unrealistically, for the restoration of the Company. Charles had taken control 'until such time as it could be turned over to the reorganized corporation'. ${ }^{32}$ Accordingly, there is evidence of 'a serious effort to secure a renewal of the old patent' in 1625, and again in 1631 - suggesting, in fact, more of a continual campaign than discrete efforts. ${ }^{33}$ The campaign continued as late as 1640, when George Sandys, Edwin's brother and the translator of Ovid and Grotius, petitioned the House of Commons for the Company's resurrection. ${ }^{34}$

What part did these transatlantic interests play in Hobbes's translation? I want to suggest that in mid-late 1628 , as Hobbes composed the prefatory materials to a volume whose title page would trumpet its origins in the Devonshire household, he judged that the aim of resurrecting the Virginia Company could best be effected by praising monarchy.

One reason for this suggestion is the distinct echo in Hobbes's antidemocratic 'Life of Thucydides' of the very language Charles used in 'resum[ing]' control of the Virginia Company in $1625 .{ }^{35}$ Remarkably, Charles used Virginia's floundering to propagandize against the evils of 'popular government', emphasizing in his published proclamation that the Company was 'incorporated of a multitude of persons of several dispositions' where 'the affairs of the greatest moment were and must be ruled by the greater number of votes and voices'. The dissention of the Virginia Company, in other words, was due to its political form - a point noted by James Ellison who says 'the early Stuart kings saw in the Virginia Company the monster of democracy, and sought to quash it'. ${ }^{36}$ In taking control, 'his Majesty's aim', Charles wrote, 'was ... to reduce that government [of the Company] into such a right course as might best agree with that form which was held in the rest of his royal monarchy'. He referred to the 'former personal differences which have heretofore happened, the reviving and continuing whereof we utterly disallow' - which could be read both as a general rebuke and as a swipe at Cavendish's illegal 1623 attempt to duel Robert Rich, Earl of Warwick.

With the potential for a reconstituted Virginia Company hanging in the balance and Charles having indicated where praise and blame should rightly be assigned, Hobbes in his 'Life of Thucydides' praises monarchy and blames democracy accordingly. In Aristotle’s Ars Rhetorica, a 1637 English brief of 
which is often ascribed to Hobbes, Aristotle advised just this studied mingling of epideictic and deliberative orations:

Praise and counsels have a common aspect: for what you might suggest in counseling becomes encomium by a change in the phrase. Accordingly, when we know what we ought to do and the qualities we ought to possess, we ought to make a change in the phrase and turn it, employing this knowledge as suggestion ... if you desire to praise, look what you would suggest; if you desire to suggest, look what you would praise. ${ }^{37}$

Hobbes evidently took to heart the lesson of the 'common aspect' of praise and suggestion. Suggesting a reconstituted Virginia Company, he praised monarchy; praising monarchy, he suggested a reconstituted Virginia Company. Sensitive, politically connected readers would likely have associated a publication coming from Cavendish's household with the Virginia and Somers Island interests, and it is noteworthy that Edward Hyde's numerous extracts from the volume, for example, give no mention of Hobbes and instead describe the translator as 'Secretary to the E. of Devon'. ${ }^{38}$ Hobbes's epideictic blame of democracy can therefore plausibly be seen as a rhetorical gesture of deference to Charles's Virginia Company historiography that, abstracted as it was from its immediate context, could also usefully articulate Stuart royalism in the broader world of print - all of which constituted, in effect, Hobbes's deliberative plea for a resurrected Virginia Company, reorganized if need be in a sufficiently hierarchical way to allay Charles's distaste for 'popularity'.

Apart from Hobbes's comments in the volume, there is little reason to think that Thucydides was a particularly apt historian to pronounce upon constitutional forms. It is possible, though unlikely, that Hobbes knew Girolamo Cardano's contention that Thucydides was a republican not a monarchist. ${ }^{39}$ More likely, he may have noted that Grotius, in his history of the Batavian Republic, had briefly cited Thucydides to prove that kingship was a 'title of honour' derived from the voluntary consent of the people, but based on Grotius's other uses of the Greek historian (not to mention Thucydides's subsequent canonization in twentieth-century international relations), the events Thucydides records were more germane to the traditional ken of the ius gentium: e.g., laws of war, the rights of ambassadors, relations among neighbours, duties of prisoners, rights of conquest, among other possible examples. ${ }^{40}$ In fact, Hobbes's first encounter with Thucydides was apparently when the Italian author of a letter that Hobbes translated into English compared Catholic barbarity in the Thirty Years' War to Thucydides's account of primitive ancient Greece. ${ }^{41}$

That Thucydides was such an unlikely author to be conscripted for the cause of monarchism helps us to see Hobbes's appeal for royal attention more clearly. ${ }^{42}$ A printed marginal note beside his translation of the infamous Corcyraean sedition further elucidates Hobbes's motive. The passage has been linked by scholars to Hobbes's brutal state of nature, but at the time, 
as the paradigmatic narrative of a community's collapse into factionalism, many contemporary readers would have associated the Corcyraean sedition with the fate of the Virginia Company, whose factions were elsewhere being compared to Italy's fractious Guelphs and Ghibellines. ${ }^{43}$ Hobbes advertises Thucydides's treatment of the passage in his 'Life'. In the passage itself, Thucydides vividly described the horrors of lawless Corcyra ravaged by dissention and war. In Corcyra's up-is-down dystopia, according to Hobbes's powerful translation:

He that could outstrip another in the doing of an evil act or that could persuade another thereto that never meant it was commended. To be kin to another was not to be so near as to be of his society because these were ready to undertake anything and not to dispute it. For these societies were not made upon prescribed laws of profit but for rapine, contrary to the laws established. ${ }^{44}$

If Thucydides is concerned here to emphasize the destruction of rogue bands in civil conflict, Hobbes, incongruously and perhaps brazenly, takes the occasion to emphasize the historical legitimacy of joint stock corporations. Anxious that the example of Corcyra not be seen as an argument against a revived Virginia Company, Hobbes adds this gloss to Thucydides's 'societies' [xunodoi]: 'The uniting of Companies under certaine Lawes, for the more profitable managing of their Trades and arts, seemeth to have beene in use then, as now." 45 'As now' had a patently ironic thrust, for it was Charles's very deviation from the ancients' 'prescribed laws of profit' that Hobbes ultimately wished to emphasize.

\section{Romance of Nations}

None of Hobbes's other marginal notes displays such a clever plea for a revival of the Virginia Company. At a broader level, however, the contemporary issues Thucydides could speak to were precisely those of a society hoping to develop a just empire. In the words of the civilian Jean Hotman, thinking with Thucydides meant thinking about 'the rights of succession of Princes, of the differences of the borders, of the taking booties of Prisoners, Reprisals, and of Sea matters' - in other words, about the law of nations. ${ }^{46}$ Two intellectual strands in particular might have revealed to Hobbes Thucydides's usefulness for such a project, I want to suggest in what now follows: literary works like the collaboratively-written Pericles and ius gentium tracts like Alberico Gentili’s De Jure Belli and Hugo Grotius's De Jure Belli ac Pacis.

Hard as it may now be to imagine, in early modern England, Thucydides was something of a marginal ancient writer. Thomas More's Utopians read Thucydides and he had been translated by Thomas Nicolls into English in 1550 , yet D. R. Woolf's analysis of the inventories of Cambridge libraries between 1535 and 1609 reveals Thucydides to be just seventeenth on the list 
of most widely held ancient historians, with Lucan appearing in twice as many inventories, Suetonius in more than three times as many, and Sallust and Caesar in nearly six times as many. ${ }^{47}$ Somewhat later, despite the fact that Robert Burton could have read Thucydides in available editions in Greek or Latin, his library of more than 1700 titles in 1640 apparently only held Thucydides because Hobbes provided Burton with a copy of his translation. ${ }^{48}$ Samual Pepys, likewise, held only the Hobbes translation..$^{49}$ Like most ancient historians, Thucydides was classed among the rhetoricians for most of the sixteenth century, yet, as evidenced by Gentili and Grotius, Thucydides had a special importance in the emerging genre of the ius gentium tract, the rise of which coincided with that of the study of history more generally: as a rough index, Oxford's first professor of history, Degory Wheare, took up his post in 1623 just as Grotius was writing De Jure Belli ac Pacis. ${ }^{50}$

By the time Hobbes came to publish his translation, however, one prominent figure in Thucydides, Pericles, had accrued a set of fairly recognizable cultural meanings. This is the first of two intellectual strains likely to have influenced Hobbes. The ardent colonialist John Dee found in Pericles someone 'wisely vnderstanding, that no other means was so easy, so ready, and so sure, for Athens to atteyn to their wished for Souerainty, among their freends and foes, dwelling about them: But if, they were Lords and Maisters of the Seas, nere and far about them'. ${ }^{51}$ Thucydides's role as the historian of empire was similarly recognized in a work published the same year in which Richard Willes concluded of attempts to recount the Spanish designs in the New World, 'to drawe Geographically the places, to wryte all their battelles, victories, and conquestes, to describe the cities rased, the townes erected, to poynte out the Capitaynes personages, to shewe theyr traueyles and good hap, it would requyre an other Homere, an other Thucydides'. ${ }^{52}$ The association Dee drew between Pericles and naval empire hardened further with the eponymous play written partly by Shakespeare (1608). ${ }^{53}$ Amidst European ius gentium debates over whether nations could claim legal sovereignty over the sea, Shakespeare, transforming the democrat Pericles into a prince much as Hobbes would do, employed the conventions of romance to dramatize a literal sovereign at sea spreading beneficence and justice across a maritime empire. ${ }^{54}$ The 'precedent-hunting' romance's promise to 'take imagination / From bourn to bourn, region to region' announced its investigation into the law of nations; at the same time, its cast of colonial 'Governors', appearing in print just as the Virginia Company substituted the Jamestown colony's president and council with a single governor, emphasized its engagement with specific questions of colonial administration (18.3-4). ${ }^{55}$ The play's resolution is something of an imperial fantasy: the death of Simonides and the marriage of Marina and Lysimachus mean that the previously atomized peoples of Tyre, Pentapolis, and Mytiline are now unified into a lawful empire through the generic prescriptions of romance, a romance not only of individuals but of nations as well. 
While Plutarch and Sidney provide the names for a number of Shakespeare's characters, passages from Thucydides narrating some of the most pressing problems of colonial administration may lurk behind Shakespeare's locale of Mytiline and the character of 'savage Cleon' (21.202). ${ }^{56}$ Shakespeare's allusions to Mytiline and Cleon point toward some of the most ethically fraught events of Greek imperial history. Cleon in book III of Thucydides famously exhorts the Athenian assembly to execute the Mytileneans in response to Mytiline's revolt from under Athenian dominion, a response subsequently deemed unnecessarily brutal by the Athenian assembly. Cleon's brutality in Thucydides follows from his unwillingness to grant that the Mytileneans had a lawful right to revolt. 'If these have justly revolted,' Cleon admonished those of his compatriots proposing moderation, 'you must unjustly have had dominion over them. ${ }^{57}$ Cleon's ferocity prompted Hobbes to call him the 'most popular and most violent' of Athenians, a perspective that echoes the Virginia Company's instructions to their colonial governors in the 1620s to treat Amerindians with equity rather than hostility. As it had for Hobbes, Cleon's insistence on punishing the Mytileneans with death had the capacity to goad Englishmen into contemplating the darkest implications of colonial enterprises. Whether Shakespeare's allusions were intended to pose colonialism's toughest ethical questions, of course, is difficult to say. What can be said, however, is that in a period of colonial expansion, Shakespeare found the figure of Pericles, the genre of romance, and the history of Greek empire useful for thinking through the practical problems of colonialism and English rights and obligations in the world.

If philhellenic romance was one arena where ancient Greek history was brought to bear on the legal and ethical problems England faced at and beyond its borders, a second though (as I have suggested) related arena is that of the ius gentium tract. As mentioned earlier, Hobbes had easy access to works by both Gentili and Grotius: alongside works including Heliodorus's classical romance Aethiopica and John Barclay's Argenis (Latin, 1621 and English, 1625), the Cavendishs' Hardwick library held Gentili’s De Legationibus (1585) and Grotius's De Antiquitate Batavica (1610), Apologeticus (1622), and De Jure Belli ac Pacis. ${ }^{58}$ Gentili's and Grotius's deeply humanist pronouncements on the ius gentium were built upon the foundation of classical exempla, which provided the raw materials for what they considered the laws common to all known peoples..$^{59}$ Dedicated as they were to uncovering common laws and customs, Grotius and Gentili cited ancient poets, dramatists, and historians with limited generic discrimination (modern writers like Guicciardini also figure prominently). Historians who wrote of wars are, however, found in greater numbers. Philip Sidney, a great admirer of Xenophon, had cited Xenophon's ability to 'imitate so excellently as to give us ... "the portraiture of a just empire" under the name of Cyrus'.$^{60}$ Xenophon's Cyropaedia, one of the few books that could reliably be found on Hobbes's table, according to Aubrey, is cited regularly in these tracts. ${ }^{61}$ Thucydides, likewise, is a constant 
presence. Even as these historians narrated conflict, they also importantly narrated those laws and customs that even adversaries agreed upon. In addition to holding storehouses of exempla, ancient histories, said Grotius, also carried the most authority:

Works of history are useful for my argument in two ways, for they provide both examples of conduct, and moral judgments upon them. Examples from the best periods and cultures [populi] carry the most authority, so I have selected those from the Ancient Greeks and Romans in preference to any others. Nor have I rejected their judgments, especially where everyone was in agreement: for while the law of nature (as I have said) may be determined in their ways, the law of nations is established solely by agreement. ${ }^{62}$

Classical histories, in other words, were both places to investigate the consensus by which the 'law of nations' might be discovered and rich sources of argumentative capital ready to be exploited by contemporary theorists.

Gentili and Grotius's variegated, at times incompatible, references to Thucydides demonstrate ancient history's role in the law of nations. In $D e$ Legationibus, Gentili, for his part, cited Thucydides to prove that nations could forbid ambassadors as Pericles once had done; that ambassadors held no rights against peoples to which they had not been sent; that neither brigands nor pirates were entitled to the privileges of the ius gentium; that ambassadors should understand the language of the person with whom they were negotiating; and, that ambassadors were 'wholly justified in doing many things in regard to which not a word has been said. ${ }^{63}$ Of these, Gentili's denial of rights for brigands and pirates is especially pertinent for Hobbes. Here, Gentili derives from Thucydides evidence of man's savage natural state:

Neither brigands nor pirates are entitled to the privileges of international law [ius gentium], since they themselves have utterly spurned all intercourse with their fellowmen and, so far as in them lies, endeavor to drag back the world to the savagery of primitive times. In that age, as you know, men passed their lives in the manner of wild beasts, and each one carried off what fortune offered to him as prey, trained to use his strength in accordance with his own impulses and to live for himself alone. In those days, as Thucydides observes, to be a robber was an honour rather than a disgrace. ${ }^{64}$

A marginal note directs readers to book V of Lucretius's De Rerum Natura for further confirmation that men once lived as wild beasts. ${ }^{65}$ Thucydides for Gentili is thus a spokesman for what Arthur Ferguson once called Tudor England's 'tradition of "hard" primitivism', the narrative of man's ascent from savagery 'as distinct from the elegiac myth of a Golden Age. ${ }^{66}$ Gentili's later work, De Iure Belli Libri Tres, now citing Thucydides twenty-six times, used the historian to illuminate such concerns as the jurisdiction over the seas; rights of conquest; the obligations of offensive and defensive alliances; the obligations of prisoners; the duties of captors; and the justice of defending the people of another nation against their sovereign. ${ }^{67}$ 
Grotius's De Jure Belli ac Pacis, which owed a number of references to Gentili, employed Thucydides similarly. ${ }^{68}$ Here, among more than sixty citations, Thucydides testified to the proper definition of a state; the freedom of the seas and the rights to hospitality; the risks of aligning with infidels; the inevitability of sin, and even the occasional legality of killing women, infants, and prisoners. ${ }^{69}$ The story of Pericles refusing to entertain a Spartan ambassador proved, as it had in Gentili, states' rights to do so, and we also find recurring Thucydides's passage on the 'old time' Greeks on which Gentili had grounded his comments on the primitive state, only here it is used to make the opposite point, emphasizing the 'general Corruption of Manners' that by the time narrated by Thucydides had 'razed and obliterated' the 'Natural Relation between all Mankind'. ${ }^{70}$ Grotius's Thucydides, as opposed to Gentili’s, was thus testimony for natural sociability rather than 'hard primitivism'. Germane to Hobbes's Virginia Company interests, Grotius quoted Thucydides four times in discussions of what he called 'Mother Cities', cities maintaining colonies (of which Athens was the prime example) and - undoubtedly interesting to Hobbes - Thucydides even elucidated the obligations stakeholders in a joint stock company had toward one another and the illegitimacy of their seeking recourse to external arbitration. ${ }^{71}$ Once adventurers contracted in good faith, in Grotius's eyes, however unequal their agreement, 'no action was allowed in Court against such an Inequality' nor could there be 'any Redress or Constraint on that Account', a view that if accepted might have prompted indignation over the Stuarts' unwarranted intervention in Virginia Company affairs. $^{72}$

\section{The Debate over Thucydides I.3-5}

Gentili's and Grotius's sometimes contradictory humanistic uses of Thucydides make generalizations about the Greek historian's overall significance within the emerging ius gentium tradition difficult, except perhaps the generalization that Thucydides was significant, and greatly so. Yet the underlying debate between Gentili and Grotius on the meaning of Thucydides I.3-5 offers a chance to see the formidable interventions a translator could make. Hobbes's intended influence on law of nations formulations can be found elsewhere - in his marginal notes suggesting the Athenians' 'dominion of the Seas', to take one example of many. These notes may have constituted an attempt to lay the textual groundwork for a fuller confutation of Grotius's claim on behalf of the Dutch East India Company that the seas were free, the likes of which confutation Selden would publish in his 1635 Mare Clausum, to Hobbes's eager expectation. ${ }^{73}$ The stakes of Thucydides I.3-5, however, included the accuracy of the Genesis story, the extent or existence of natural obligations, and the capacity of men, as one of Hobbes's marginal notes put it, to ' $\mathrm{gr}[\mathrm{o}] \mathrm{w}$... civil'. ${ }^{74}$ All of these were significant seventeenth-century 
debates, in large measure because of their implications for English colonialism.

We miss something fundamental about how the early modern law of nations was formulated if we fail to observe that translation of a passage like Thucydides I.3-5 provided someone like Hobbes the opportunity to influence debates. While a thorough analysis of Hobbes's relationship to the Greek original is both beyond my means and the scope of this article, a brief discussion of Hobbes's rendering of Thucydides I.3-5 can suggest his translation's implications for colonial concerns. Hobbes's particular choices reveal a translator eager to adopt Gentili's account of human history, an account that appeared in modified form in Virginia Company propaganda that linked England with Athens and implicitly proposed that barbarian natives, with proper tutelage, could evolve into a civilized culture equal with England, much as England herself had purportedly evolved from savagery. ${ }^{75}$ Confirmation of this comparative history could already be found in Thucydides, who wrote that the 'old Greeks used the same form of life that is now in force amongst the barbarians of the present age', but Hobbes seems to have wanted to emphasize it further. ${ }^{76}$ Where Grotius had stressed time's 'Corruption of Manners', Hobbes's translation and notes to Thucydides I.3-5 bolster Gentili's story of growing civility. This concern is seen most clearly on two occasions.

As it is in Hobbes's friend Bacon's New Atlantis, navigation was for many in Stuart England a signal of scientific advancement that carried with it a strong hint of moral and spiritual superiority. ${ }^{77}$ In Thucydides I.3, the Greek author tells of the first time Greek cities joined together to form a political community, the Trojan War. The passage garnered the attention of commentators who were concerned with the origins of political communities. The Greeks' advantageous union was made possible, according to Thucydides, by cities 'becoming more experienced in seafaring'. ${ }^{78}$ If 'experience in seafaring' provided the Greek cities with the necessary means for effective political union in Thucydides's original, Hobbes's rendering subordinates the procedural value of Thucydides's 'experience' in favour of a more explicitly teleological narrative. Navigation was no longer something the Greeks became 'more experienced in' (David Grene suggests 'they used the sea more') but, rather, something they had 'now received'. Noting Hobbes's departure from the original in using 'now received', Grene, in an otherwise sparsely annotated edition, feels compelled to point out: 'The Greek says, "But on that expedition they came together inasmuch as now they used the sea more". "79 Positioning Thucydides along Gentilian rather than Grotian lines meant Hobbes's departure from Bacon, whose New Atlantis adopted the more Grotian narrative that 'about three thousand years ago ... the navigation of the world ... was greater than at this day'. ${ }^{80}$ The effect of rendering navigation as something 'received' rather than 'experienced' was compounded by another alteration Hobbes made. Where Thucydides says the 'old time' Greeks 'increased their 
contacts by sea' (in Lattimore's translation) or 'began more often to cross over' (Grene's), Hobbes renders it instead 'began to cross over', omitting evidence of previous seafaring, a choice that, like 'received' a few lines earlier, made Thucydides speak to the first origins of Greek navigation, rather than to its relative use. ${ }^{81}$

Hobbes's silent intervention here can be seen as an attempt to maintain Thucydides as a corroborator of Gentili's 'hard primitivism' against the perceived threat of Grotian natural society. The stakes of this intervention would become clearest in Leviathan, where, in the famous paragraph describing life in the state of nature as 'solitary, poore, nasty, brutish, and short', Hobbes insists that in that state, there was 'no Navigation'. ${ }^{82}$

Hobbes's marginal notes continue the assault on Grotian natural society. Thucydides I.3-5, his notes suggest, is 'A Digression, touching the Piracie \& Robberies of old time; with other Notes of Saulvagenesse'; in old time, Hobbes instructs his readers, 'Robbing had in honour' and 'The continuall wearing of Armour [was] in fashion' due to the danger of daily life. ${ }^{83}$ The original, it is true, warranted these interpretations, but Hobbes goes out of his way to confirm Gentili's account of the Athenians' ascent from beastliness in his note upon the 'golden grasshoppers, which [the newly civil Athenians] were wont to bind up in the locks of their hair'. The grasshopper helped Hobbes solidify the relation between Thucydides I.3-5 and the passage in Lucretius V to which Gentili referred in which the Roman poet found evidence of human origins in the molting of grasshoppers. Hobbes posits, 'The Athenians, holding themselves to be sprung from the ground they lived on, wore the Grasshopper for a kinde of Cognizance, because that Beast is thought to be generated of the earth.' ${ }^{84}$ For Lucretius:
All sorts of birds disclosed in that first spring
Leaving their shells, betooke them to their wing,
And sought foode to sustaine their ranging lives
As grasshoppers whom the hott summer drives
Out of their winter coats. Then in the ground
Moysture and heate did very much abound,
Which wheresoere earth yielded them fitt place
Impregnated her womb with humane race. ${ }^{85}$

Hobbes's Lucretian and Gentilian rendering of a passage already critical to the emerging ius gentium tradition suggests the influence Hobbes thought he might have on successive ius gentium theories.

Similarly telling is Hobbes's rendering of the phrase in Thucydides I.5 'lived in by villages', [kata kômas], into 'scatteringly inhabited'. According to Grene, where Hobbes's Thucydides says 'men ... falling upon towns unfortified and scatteringly inhabited, rifled them and made this the best means of their living', 'the phrase is hardly fitly rendered "scatteringly"'. ${ }^{86}$ Once again, ius gentium debates in the context of colonialism inform Hobbes's translation here. 'The key argument for the occupation of North America by the 
English', Richard Tuck points out, was that, in the words of John Donne's 1622 sermon to the Virginia Company, 'a man [does not] become Lord of a Maine Continent, because he hath two or three cottages in the skirts therof' ${ }^{87}$ 'Filling' the land was the prime justification for 'planting', and English colonialists undoubtedly welcomed confirmation of Greek precedent for 'filling'. As opposed to 'lived in by villages', 'scatteringly', therefore, opened the way for arguments built upon habitation patterns such as the one Hobbes was later to make in Leviathan - that settlers 'are not to exterminate the people they find there; but constrain them to inhabit closer together' ${ }^{88}$

If Hobbes's treatment of Thucydides I.3-5 reveals how a classical history could both be made to conform to colonialist assumptions about savagery and give historical precedence for colonialism itself, the translation on the whole should nevertheless not be read as an apology for unbridled colonialism. Because of the failure of the Sicilian expedition in book eight, Thucydides has often been read as an object-lesson in imperial overreaching, and a number of examples from Hobbes's translation also tell a more nuanced story of how Thucydides could authorize laws and norms in line with the demands of equity - authorize, that is, a 'just empire', to recall's Sidney's praise of Xenophon. An easily overlooked context for Hobbes's censure of Cleon's brutality, mentioned earlier, is English outrage over the Dutch execution of ten English merchants in Amboyna, Indonesia in 1623. The Dutch originally claimed their right to punish the English merchants 'according to the law of Nations' by virtue of Dutch 'dominion' over Amboyna, but eventually English pressure won out and the Dutchmen responsible, including the infamous governor Van Speult, came up for trial in the spring of $1628 .^{89}$ In the same month as Hobbes's Thucydides was published, December 1628, Charles silenced voices from within the East India Company whose wounds were reopened by the trial but whose virulent anti-Dutch outrage complicated foreign policy. ${ }^{90}$ In such a climate, denunciation of Dutch cruelty - provided it is such - could only be accomplished by indirection like Hobbes's. The censure of Cleon was accompanied by a similar censure of the 'cruell decree of the Athenians in their passion against the Mityleans' and, later, of 'The barbarous cruelty of the Thracians' ${ }^{91}$ Such passages remind us that, whatever the reputation Hobbes has gained for amorality, nature's prohibition of cruelty was for Hobbes one of the 'natural laws whose observance does not cease even in war'..$^{92}$

Hobbes also lodges his denunciation of an 'unjust proceeding of the Lacedaemonians' in which the Spartans renege on an agreement to give the Plataeans with whom they were warring a fair trial if the Plataeans would 'give up their city voluntarily'. ${ }^{93}$ When the Spartans ignore the Plataeans' plea for equity, based in part on the argument that 'by the law of all nations it is lawful to repel an assailing enemy', the Spartans' double dealing prompts Hobbes's rebuke: 'It doth not appeare by any thing in the time of this War that the Lacedaemonians deserved any reputation for Justice, but contrarily 
they appeare by this and divers other actions, not to have esteemed of justice at all, when it crossed their owne interest of passion. ${ }^{94}$

If Hobbes's rebukes here are relatively straightforward, his marginal notes sometimes work on a subtler level. For example, the famous Articles of Peace between Athens and Sparta declared,

Touching the publique Temples, it shall bee lawful to whomsoever will to sacrifice in them and to have access unto them and to ask counsel of the oracles in the same and to send their Deputies unto them, according to the custom of his country, securely both by Sea and Land.

Remarkably, Hobbes here glosses 'Deputies' as 'Ambassadors about matters of religion' - people who, as readers of Gentili’s De Legationibus or Jean Hotman's The Ambassador would have known, were in legal terms next to unassailable. ${ }^{95}$ If such a gloss conveniently found a legal precedent for 'secure' colonialism that could easily be deployed to authorize a retaliatory 'just war', it nevertheless also substantiated the more laudable ius gentium project of protecting ambassadors from violence. Much like his later argument in Leviathan, that sovereigns' 'augmentation of dominion' was permissible in the face of rivals of 'insatiable appetite, or Bulimia' who pursue 'acts of conquest ... farther than their security requires', Hobbes's translation could serve both to authorize colonialism and to bridle it. ${ }^{96}$

\section{Translations, Title Pages, and Patents}

Hobbes's many interventions into the ius gentium debates are impossible here to flesh out in the detail they deserve, and to the extent that I have done so at all, it has been, in any case, only part of my project in this article. For I want to argue not that Hobbes was a rogue humanist cynically manipulating texts to alter doctrine and policy, but that Hobbes's intellectual climate - a humanistic and colonial climate encompassing the romance as much as the ius gentium tract - considered translating classical histories into English a contribution to a just English empire. The case of George Sandys, mentioned earlier as the translator of Ovid and Grotius, provides an instructive model. While Ovid's claim to the label of 'history' may today seem slight, Degory Wheare considered Metamorphoses a 'chronicle' that 'comprehended' 'the Trojan War, the Expedition of the Argonauts, the Histories of Perseus, Oedipus, Hercules, Theseus and some others'. ${ }^{97}$ Sandys also translated Virgil's Aeneid, which, like Ovid's Metamorphoses, provided key matter for the ius gentium tracts. Sandys's intentions - and rewards - can therefore be suggestively considered alongside those of Hobbes and their contemporaries, not least because Sandys's 1626 Ovid and Hobbes's 1628 Thucydides each bore elaborate engraved title pages crafted by the artist beloved by colonialists, Thomas Cecil, whose work also included an imperial engraving for the famous title 
page of Bacon's posthumous Sylva Sylvarum (1627), a title page engraving for the continuation of John Smith's History of Virginia (1629), a map for $A$ Relation of Maryland (1635), and the famous painting of Queen Elizabeth astride a horse large enough to cross the Atlantic in one bound, Truth Presents the Queen with a Lance (1625). ${ }^{98}$

Sandys translated Virgil, it has been suggested, attempting to win the patronage of wealthy Virginia Company investors like the Earls of Pembroke and Southampton. ${ }^{99}$ The resulting text suggests affinities at every turn between Englishmen and heroic, colonizing Trojans. Sandys's Ovid translation, meanwhile, completed when Sandys was in Virginia, bragged of its having been 'bred in the New-Worlde, of the rudenesse whereof it cannot but participate; especially having Warres and Tumults to bring it to light', and thus held English learning aloft against New World barbarity. In it, Sandys largely hewed closely to Ovid's original, yet, like Hobbes, Sandys occasionally suggested the barbarity of the New World by altering key phrases. To surmise Ovid's potential importance to ius gentium debates, Stuart England did not have to look past Grotius's Mare Liberum (1609). Ovid's 'usus communis aquarum est' [the enjoyment of water is a common right] had underpinned Grotius's claim for a 'free sea' in 1609, and was of enough significance for Grotius to reproduce what he called this 'noble passage' again in an unpublished reply to the Scotch jurist William Welwood's An Abridgement of All Sea-Lawes (1613) (another book, incidentally, held in the Hardwick library). ${ }^{100}$ As with Thucydides, the commercial stakes of translation were considerable: the goal in this debate was not intellectual vindication but rather fishing rights and the control of prizes. In this context, it should not be surprising that Sandys's heavily annotated English Ovid reaped him extraordinary royal favour. On 24 April 1626, Charles took the rare step of granting Sandys a twenty-one-year patent for the exclusive printing and selling of Ovid: 'the better to encourage him and others to imploie theire labours and studies in good literature'. ${ }^{101}$ If it had not been already, the word was now out that English translations of the classics, so useful for formulating the law of nations, would or could win lucrative remuneration.

The spate of classical histories appearing during this period - of which Hobbes's Thucydides must be considered a part - should, I think, be considered in this light. May's 1627 and 1630 Pharsalia, Philemon Holland's 1632 Cyrupaedia, and Parliament sergeant-at-arms Edward Grimeston's 1633 Polybius all testify to the vogue for translation that Charles's patents encouraged, and each of these works was as fundamental to the growing ius gentium literature as Thucydides and Ovid were. ${ }^{102}$ One of the best peeks we have of the work these translations were intended to perform comes from some prefatory poems attached to Philemon Holland's Cyrupaedia, a work whose title page visually linked Charles with the great empire-builder Cyrus and Holland with Xenophon himself. ${ }^{103}$ The prefatory poems by Thomas Farnaby and Thomas Heywood make the motives of translatio imperii clear. Farnaby, 
a prominent translator who himself was in 1632 granted a lucrative patent for the printing of classical translations, asked in prefatory verses 'why should Spanish, French and other Nations / Rather than wee, make use of such Translations?'. ${ }^{104}$ Heywood employed the same translation/nation rhyme in his encomium to Holland: 'Acknowledging by many a sweet Translation, / What profit Thou hast brought unto our Nation.' 105 Farnaby cast the now elderly Holland as a conquering captain who 'truce on Death [his] pow'rfull Art had prest', the 'art' of translation a parallel to the arts of war and peace governed by the law of nations.

\section{Conclusion}

Having looked at the political, intellectual, and literary climate in which Hobbes's Thucydides was published, we are finally in a position to review. This article began by asking why Hobbes translated Thucydides and published his translation in 1628. I have suggested that Thucydidean history provided a means for Hobbes not only to deliberate over the law of nations but to shape it. Grounding this claim has been the assumption that humanistic, early modern England developed its conceptions of the law of nations not only through its physical and political encounters with other nations and peoples (gentes) but through its intellectual encounters with literature and history, which were themselves overlapping and interpenetrating categories. The story I have told here consciously steers between what might be called the Kantian Scylla of describing the law of nations in teleological terms of growing civility and the Schmittian Charybdis of describing it as a pure instrument of seizure. Hobbes's Thucydides had elements of both. In addition to providing intellectual sustenance and historical precedence for colonialism, it also intervened with tight ethical limits on raw power, at various points demanding justice from empire and denouncing its manifest cruelties. It is evident that the law of nations evoked by Hobbes's Thucydides is a law from which colonialists could gain by 'punishing' supposed violators, but so too is it evident that Hobbes's world was not a juridical void - a view often ascribed to him. Instead, Hobbes's hard primitivism underscored for him as it had for Gentili the need for positive declarations of law - via history, via precedent - that could ultimately ensure that interactions among nations and peoples remained in juridical space rather than devolving into the fabled barbaric primitivism of the first men: better that history's law of nations be shown to provide for colonialism, in other words, than colonialism to take place outside the reach of law. ${ }^{106}$ 


\section{Notes}

1 Only one study, for example, approaches Hobbes's translation in terms of literary style. See Robin Sowerby, 'Thomas Hobbes's Translation of Thucydides', Translation E Literature, 7:2 (1998), 147-69. Depending upon whether portions of the anonymous Horae Subsecivae (1620) are accepted as Hobbes's, the Thucydides translation may in fact be Hobbes's first published work.

2 Eric Nelson, 'General Introduction', in Thomas Hobbes: Translations of Homer, ed. Eric Nelson, 2 vols (Oxford, Clarendon Press, 2008); A. P. Martinich, 'Hobbes's Translations of Homer and Anticlericalism', The Seventeenth Century, 16:1 (2001), 147-57; Paul Davis, 'Thomas Hobbes's Translations of Homer: Epic and Anticlericalism in Late Seventeenth-Century England', The Seventeenth Century, 12:2 (1997) 572-3; Patricia Springborg, 'Hobbes, Heresy, and the Historia Ecclesiastica', Journal of the History of Ideas, 55:4 (1994), 553-71; Quentin Skinner, Reason and Rhetoric in the Philosophy of Hobbes (Cambridge, Cambridge University Press, 1996).

3 Jeffrey R. Collins, The Allegiance of Thomas Hobbes (Oxford, Oxford University Press, 2005); Kinch Hoekstra, 'The De Facto Turn in Hobbes' Political Philosophy', in Leviathan after 350 Years, ed. Tom Sorell and Luc Foisneau (Oxford, Clarendon Press, 2004), pp. 33-73.

4 Clifford W. Brown, Jr., 'Thucydides, Hobbes, and the Derivation of Anarchy', History of Political Thought, 8:1 (1987), 33-62; George Klosko and Daryl Rice, 'Thucydides and Hobbes's State of Nature', History of Political Thought, 6:3 (1985), 405-9; Richard Schlatter, 'Thomas Hobbes and Thucydides', Journal of the History of Ideas, 6:3 (1945), 350-62; G. Slomp, 'Hobbes, Thucydides and the Three Greatest Things', History of Political Thought, 11 (1990), 565-86.

5 Thomas Hobbes, Old Catalogue, Chatsworth, MSS Hobbes E.1.A, 86, 83; Maurice Keen, The Laws of War in the Late Middle Ages (London, Routledge \& K. Paul, 1965), pp. 10-11; Alberico Gentili, De Iure Belli Libri Tres, trans. John C. Rolfe, 2 vols (Oxford, Clarendon Press, 1933), II, 9. See also Richard Tuck, Natural Rights Theories: Their Origin and Development (Cambridge, Cambridge University Press, 1979), p. 42. For discussion of Hobbes's role in contemporary international law debates, see K. Akashi, 'Hobbes's Relevance to the Modern Law of Nations', Journal of the History of International Law, 2 (2000), 199-216. On Thucydides and international law, see George A. Sheets, 'Conceptualizing International Law in Thucydides', The American Journal of Philology, 115 (1994), 51-73.

6 For the shift in Hobbes's thinking about the law of nations, see David Armitage, 'Hobbes and the Foundations of Modern International Thought', in Rethinking the Foundations of Modern Political Thought, ed. Annabel S. Brett, James Tully, and Holly Hamilton-Bleakley (Cambridge, Cambridge University Press, 2006), pp. 219-35.

7 Hugo Grotius, The Rights of War and Peace, ed. Richard Tuck, 3 vols (Indianapolis, IN, Liberty Fund, 2005), p. 1755. Grotius goes on to include Gentili's as among the 'attempts to supply the deficit'.

8 John Aubrey, 'Thomas Hobbes', in Aubrey's Brief Lives, ed. Oliver Lawson Dick (Jaffrey, NH, David Godine, 1999; first ed. London, 1949), p. 149. Hobbes, says Aubrey, 'often repented' these years, but Aubrey was already alert to the possibility 
that Hobbes took more from this reading than he liked to admit ('perhaps he was mistaken').

9 Thomas Hobbes, 'Verse Autobiography', in Leviathan: with Selected Variants from the Latin Edition of 1668, ed. E. M. Curley (1679 [Latin]; 1680 [English]; Indianapolis, Hackett, 1994).

10 Thomas Hobbes, The Peloponnesian War: The Complete Hobbes Translation, ed. David Grene (Chicago, University of Chicago Press, 1989), pp. 572-3. I quote in this essay both from Grene's edition and from Hobbes's original 1629 (really 1628) edition, which contains marginal notes by Hobbes not printed in Grene. To distinguish the two, I cite Hobbes's seventeenth-century edition as Eight Bookes of the Peloponesian Warres and Grene's twentieth-century edition as The Peloponnesian War: The Complete Hobbes Translation. One difference in these titles provides a possible area for further study. That Hobbes considered Thucydides a historian of 'warres' plural raises the possibility that he had not yet come to his later definition of war 'not as actual fighting; but ... the known disposition thereto'. See Thomas Hobbes, Leviathan, ed. C. B. MacPherson (London, Penguin Books, 1968), p. 186.

11 Miriam M. Reik, The Golden Lands of Thomas Hobbes (Detroit, Wayne State University Press, 1977), p. 37; Jonathan Scott, 'The Peace of Silence: Thucydides and the English Civil War', in The Certainty of Doubt: Tributes to Peter Munz, ed. Miles Fairburn and Bill Oliver (Wellington, NZ, Victoria University Press, 1996), pp. 90-116; Johann P. Sommerville, Thomas Hobbes: Political Ideas in Historical Context (London, Macmillan, 1992), pp. 9-10; David Norbrook, Writing the English Republic: Poetry, Rhetoric and Politics, 1627-1660 (Cambridge, Cambridge University Press, 1999), pp. 58-62; Hobbes, The Peloponnesian War, p. 572.

12 Norbrook, Writing the English Republic, p. 44; Hobbes, Eight Bookes of the Peloponesian Warres, sig. a1v.

13 Richard Cust, The Forced Loan and English Politics: 1626-1628 (Oxford, Clarendon Press, 1987), pp. 84, 102 n. 13, 106.

14 Skinner, Reason and Rhetoric in the Philosophy of Hobbes, p. 224; Sommerville, Thomas Hobbes, p. 9.

15 Sommerville, Thomas Hobbes, pp. 9-10, draws this portrait with the help of Hobbes's later claim that the ultraroyalist preacher Roger Manwaring 'preached my doctrine' in 1627. But see Collins, The Allegiance of Thomas Hobbes, p. 59, for the counterargument that Hobbes, late in his life, should be considered a 'hostile witness' on his own biography.

16 Norbrook, Writing the English Republic, p. 44; Cust, The Forced Loan and English Politics: 1626-1628, pp. 84, 102 n. 13, 106; Jess Stoddart Flemion, 'The Struggle for the Petition of Right in the House of Lords: The Study of an Opposition Party Victory', The Journal of Modern History, 45:2 (1973), 195 n. 10; P. R. Seddon (ed.), Letters of John Holles, 1587-1637, 3 vols (Nottingham, Thoroton Society, 1975), II, 375-6.

17 Mary Keeler, Maija Cole, and William Bidwell (eds), Proceedings in Parliament, 1628, 5 vols (New Haven, Yale University Press, 1983), V, 524; Jess Flemion, 'A Savings to Satisfy All: The House of Lords and the Meaning of the Petition of Right', Parliamentary History, 10:1 (1991), 27-44 (p. 42).

18 On reason of state, see G. Baldwin, 'Reason of State and English Parliaments, 1610-1642', History of Political Thought, 25:4 (2004), 620-41; David S. Berkowitz, 'Reason of State in England and the Petition of Right, 1603-1629', in Staatsräson: 
Studien Zur Geschichte Eines Politischen Begriffe, ed. Roman Schnur (Berlin, Duncker und Humblot, 1975), pp. 165-212; T. Cogswell, "In the Power of the State”: Mr Anys's Project and the Tobacco Colonies, 1626-1628', English Historical Review, 50 (2008), 35-64 (pp. 46, 60).

19 Keeler, Cole, and Bidwell (eds), Proceedings in Parliament, 1628, p. 435; Sommerville, Thomas Hobbes, p. 10 n. 18.

20 Keeler, Cole, and Bidwell (eds), Proceedings in Parliament, 1628, p. 324.

21 Ibid., p. 323.

22 Flemion, 'A Savings to Satisfy All: The House of Lords and the Meaning of the Petition of Right', pp. 34-6.

23 Sidney Lee and Victor Slater, 'Cavendish, William, Second Earl of Devonshire (1590-1628)', in Oxford Dictionary of National Biography (Oxford, Oxford University Press, 2004).

24 Keeler, Cole, and Bidwell (eds), Proceedings in Parliament, 1628, p. 329.

25 Ibid., p. 324.

26 See Skinner, Reason and Rhetoric in the Philosophy of Hobbes, pp. 244-9, for Hobbes's rhetorical moves in his 'Life of Thucydides'. On the general importance of the epideictic tradition to early modern political and intellectual culture, see David Colclough, 'Verse Libels and the Epideictic Tradition in Early Stuart England', Huntington Library Quarterly, 69:1 (2006), 15-30.

27 Noel Malcolm, 'Hobbes, Sandys, and the Virginia Company', The Historical Journal, 24 (1981), 297-321; Noel Malcolm, Aspects of Hobbes (Oxford, Oxford University Press, 2002), pp. 53-79.

28 Malcolm, Aspects of Hobbes, p. 73.

29 Wesley Frank Craven, 'An Introduction to the History of Bermuda: VI, the Revised Plan of Settlement', William and Mary College Quarterly, 18:1 (1938), 45-6 n. 11.

30 J. H. Lefroy (ed.), Memorials of the Discovery and Early Settlement of the Bermudas or Somers Islands, 1515-1685 (London, Longmans Green and Co., 1877), I, 532; Henry C. Wilkinson, The Adventurers of Bermuda: A History of the Island from Its Discovery until the Dissolution of the Somers Island Company in 1684, 2nd ed. (London, Oxford University Press, 1958), p. 220.

31 Wilkinson, The Adventurers of Bermuda, pp. 328, 343, Lefroy (ed)., Memorials, II, 718-31.

32 Wesley Frank Craven, Dissolution of the Virginia Company: The Failure of a Colonial Experiment (New York, Oxford University Press, 1932), p. 328.

33 Ibid., p. 329.

34 James Ellison, George Sandys: Travel, Colonialism and Tolerance in the Seventeenth Century (Cambridge, D.S. Brewer, 2002), p. 144.

35 Quotations from Charles's proclamation are taken from 'Proclamation Settling the Affairs of Virginia', in Foundations of Colonial America: A Documentary History, ed. W. Keith Kavenagh (New York, Chelsea House, 1973), p. 1723.

36 Ellison, George Sandys, p. 145.

37 Aristotle, The 'Art' of Rhetoric, trans. John Henry Freese (London, Harvard University Press, 1926), I.ix.36, pp. 101-3. Andrew Fitzmaurice also suggests Donne's indebtedness to this passage in his useful study of the oratorical and humanist facets of Virginia Company propaganda. See Andrew Fitzmaurice, Humanism and America: An Intellectual History of English Colonisation, 
1500-1625 (Cambridge, Cambridge University Press, 2003), p. 103.

38 Edward Hyde, Bodleian Library, MSS Clarendon 127, fol. 50r.

39 Anthony Grafton, What Was History?: The Art of History in Early Modern Europe (Cambridge: Cambridge University Press, 2007), p. 183.

40 Hugo Grotius, A Treatise of the Antiquity of the Commonwealth of the Battavers, trans. Thomas Woods (London, 1649), sig. b2r-v, originally, Liber De Antiquitate Reipublicae Batavicae (Leiden, 1610).

41 Micanzio to Cavendish 12 March 1621: 'They use every where such barbaritie, as savours not of Christians, but of their ancient derivation from Gothes, and Mahometans. Leopold in Tirole and he $\mathrm{y}^{\mathrm{t}}$ is governour in Carinthia have $\mathrm{w}^{\text {th }}$ severe edicts cutt of all commerce $\mathrm{w}^{\text {th }}$ us, and under pretence that Soldiers shall not passe that way, they use the most unreasonable extortion upon passengers and Merchants that ever was heard off. One may new looke to see againe that tyme whereof Thucidides maketh mention, that amongt the Graecians to be a robber was a Title of Honour, so these men will make oppression to be a secret of Empire.' See Fulgenzio Micanzio, Lettere a William Cavendish (1615-1628), trans. Thomas Hobbes, ed. Roberto Ferrini (Rome, Marianum, 1987), p. 131.

42 Hobbes suggests that his monarchical language was composed some years after he had actually translated Thucydides. He notes in his epistle 'To the Readers': 'After I had finished [the translation], it lay long by mee, and other reasons taking place, my desire to communicate it ceased', Hobbes, Eight Bookes of the Peloponesian Warres, sig. a4r.

43 For the link between Corcyra and Hobbes's state of nature, see, for example, Brown, 'Thucydides, Hobbes, and the Derivation of Anarchy'. For the comparison with Italian factionalism, see Cogswell, "In the Power of the State”: Mr Anys's Project and the Tobacco Colonies, 1626-1628', p. 37.

44 Grene (ed.), The Peloponnesian War: The Complete Hobbes Translation, p. 205.

45 Hobbes, Eight Bookes of the Peloponesian Warres, p. 198. At least one seventeenth-century reader took special note of Hobbes's translation and annotation of this passage. A reader of British Library shelfmark Eve. b.38, perhaps the diarist and naturalist John Evelyn himself, made marginal pencil marks on most of this page. A relevant distinction is the one Hobbes makes in Leviathan II.22 between corporations that work as part of the body politic like muscles and corporations that infect it.

46 Jean Hotman, The Ambassador (London, V. S. for James Shawe, 1603), sig. c1v.

47 D. R. Woolf, Reading History in Early Modern England (Cambridge, Cambridge University Press, 2000), p. 145.

48 Burton's Eight Bookes of the Peloponnesian Warre is inscribed in Burton's hand 'Ex dono Authoris': Nicolas K. Kiessling (ed.), The Library of Robert Burton (Oxford, Oxford Bibliographical Society, 1988), pp. 302-3. A second copy given by Hobbes survives in the collection of the Dr Williams Library: see Peter Lindenbaum, 'Dispatches from the Archives', TLS, no. 5383 (2006), 15. Besides Burton and Pepys, other owners of Hobbes's Thucydides include Sir Kenelm Digby, a friend of Hobbes's whose name and motto appear on the title page of a copy now at the Houghton Library at Harvard University, and Francis Dee, a Cambridge-educated divine who in 1629 was chaplain to the ambassador to Paris and who bequeathed his copy along with the rest of his library to St John's College, Cambridge, where this copy now resides. 
49 Robert Latham (ed.), Catalogue of the Pepys Library at Magdalene College, Cambridge, vol. I (Woodbridge, D. S. Brewer, 1978).

50 In fact, Wheare's De Ratione et Methodo Legendi Historias (1625), running through the ancient historians in chronological order, quoted many of the same laudatory passages Hobbes would in his praise of Thucydides. On Wheare, see J. H. M. Salmon, 'Precept, Example, and Truth: Degory Wheare and the Ars Historica', in The Historical Imagination in Early Modern Britain: History, Rhetoric, and Fiction, 1500-1800, ed. Donald R. Kelley and David Harris Sacks (Cambridge, Woodrow Wilson Center Press and Cambridge University Press, 1997), pp. 11-36.

51 John Dee, General and Rare Memorials Pertayning to the Perfect Arte of Nanigation (London, John Daye, 1577), on which, generally, see William H. Sherman, John Dee: The Politics of Reading and Writing in the English Renaissance (Amherst, University of Massachusetts Press, 1995).

52 Pietro Martire d' Anghiera, Richard Eden, and Richard Willes, The History of Tranayle in the West and East Indies, and Other Countreys Lying Eyther Way (London, Richarde Iugge, 1577), p. 467.

53 For current thinking on Pericles's complicated textual history, see Brian Vickers, Shakespeare, Co-Author: A Historical Study of Five Collaborative Plays (Oxford, Oxford University Press, 2002), pp. 291-332, and MacDonald P. Jackson, Defining Shakespeare: Pericles as Test Case (Oxford, Oxford University Press, 2003).

54 For Pericles in relation to jurisdiction of the sea debates, see Bradin Cormack, 'Marginal Waters: Pericles and the Idea of Jurisdiction', in Literature, Mapping, and the Politics of Space in Early Modern Britain, ed. Andrew Gordon and Bernhard Klein (Cambridge, Cambridge University Press, 2001), pp. 155-80.

55 Simon Palfrey, Late Shakespeare: A New World of Words (Oxford, Clarendon Press, 1997), p. 48. References to Pericles are to Stephen Greenblatt et al. (eds), The Norton Shakespeare (London, W. W. Norton, 1997), and are cited in the text. For the date of the reorganization, see Fitzmaurice, Humanism and America, p. 70.

56 Arthur F. Kinney, 'Sir Philip Sidney and the Uses of History', in The Historical Renaissance: New Essays on Tudor and Stuart Literature and Culture, ed. Heather Dubrow and Richard Strier (Chicago, University of Chicago Press, 1988), pp. 293-314; Simon Palfrey, Late Shakespeare, pp. 52-6.

57 Hobbes, Eight Bookes of the Peloponesian Warres, p. 163; Grene (ed.), The Peloponnesian War: The Complete Hobbes Translation, p. 179.

58 Hobbes, Old Catalogue, fols 90 (Heliodorus), 57, 59 (Barclay), 85 (Gentili), 86 (Grotius).

59 'Humanism' is a contested word in recent scholarship in political thought. Richard Tuck, The Rights of War and Peace, Chapter 1, links humanism to changing views on pre-empting one's enemies. I use a more limited sense of the term here to refer to the importance of the studia bumanitatis for these writers, without reference to these writers' particular claims. I give a fuller defence of describing Gentili as a humanist in 'Gentili, the Poets, and the Laws of War', in The Roman Foundations of the Law of the Nations: Alberico Gentili and the Justice of Empire, ed. Benjamin Straumann and Benedict Kingsbury (Oxford, Oxford University Press, 2010).

60 Philip Sidney, An Apology for Poetry, or, the Defence of Poesy, ed. R. W. Maslen and Geoffrey Shepherd, 3rd ed. (Manchester, Manchester University Press, 2002), p. 87.

61 John Aubrey, 'Thomas Hobbes', in Aubrey's Brief Lives, p. 154. 
62 Grotius, The Rights of War and Peace, p. 1758.

63 Alberico Gentili, De Legationibus Libri Tres, trans. Gordon J. Laing, 2 vols (New York, Oxford University Press, 1924), II, 69 (forbidding ambassadors), 62 (rights), 79 (brigands and pirates), 150 (language), 180 (role of instructions). Given that Virginia Company propaganda often cast colonists as ambassadors, Gentili's tract would likely have been a valuable source of legal and ethical guidance. A true declaration of the estate of the colonie in Virginia, for example, spoke of Amerindians having 'violated the lawe of nations, and [having] used our Ambassadors as Ammon did the servants of David: If in him it were a just cause to warre against the Ammonites, it is lawfull, in us, to secure ourselves, against the infidels': quoted in Fitzmaurice, Humanism and America, p. 147.

64 Gentili, De Legationibus, p. 79; Alberico Gentili, De Legationibus Libri Tres (London, T[homas] Vautrollerius, 1585), sig. g3r.

65 For recent statements of the importance of Lucretius to Hobbes, see Jon Parkin, 'Hobbism in the Later 1660s: Daniel Scargill and Samuel Parker', The Historical Journal, 42:1 (1999), 85-108, and Springborg, 'Hobbes, Heresy, and the Historia Ecclesiastica'.

66 Arthur B. Ferguson, Clio Unbound: Perception of the Social and Cultural Past in Renaissance England (Durham, NC, Duke University Press, 1979), p. 358. Ferguson traces the 'hard primitivism' tradition in Tudor England through the works of Thomas Starkey and Juan Luis Vives, pp. 356-72. Richard Tuck has speculated that Hobbes heard Gentili lecture at Oxford: see Tuck, Rights of War and Peace, p. 17.

67 Gentili, De Iure Belli Libri Tres, pp. 384 (seas), 19, 308 (conquest), 388 (alliances), 242 (hostages), 364-65 (captors), 74 (intervention). This section, like the paper on the whole, benefited from discussion with Kinch Hoekstra, whose observations can now be found in 'Gentili, Thucydides, and the Justification of Pre-Emption', in Alberico Gentili: La Salvaguardia dei beni culturali nel diritto internazionale (Milan, Giuffré, 2008), pp. 115-28.

68 On Grotius's debts to Gentili, including discussion of a 1623 letter of Grotius's 'urgently expecting' a copy of Gentili's De Iure Belli, see Peter Haggenmacher, 'Grotius and Gentili: A Reassessment of Thomas E. Holland's Inaugural Lecture', in Hugo Grotius and International Relations, ed. Hedley Bull, Benedict Kingsbury, and Adam Roberts (Oxford, Clarendon Press, 1990), pp. 133-77, esp. pp. 152-3.

69 Grotius, The Rights of War and Peace, pp. 257 (state), 430 (seas), 446 (hospitality), 836 (infidels), 993 (sin), 1283 (women and infants), 1286 (prisoners).

70 Grene (ed.), The Peloponnesian War: The Complete Hobbes Translation, I.5, 3; Grotius, The Rights of War and Peace, pp. 904, 821-2.

71 Grotius, The Rights of War and Peace, pp. 320, 326-7, 674 (colonies). Before Grotius, Bodin had also cited Thucydides in his discussion of corporations. See Jean Bodin, The Six Bookes of a Common-Weale, trans. Richard Knolles (London, [Adam Islip] for G. Bishop, 1606), p. 362, in the chapter headed 'Of Corporations, and Colledges, Estates, and Communities, and what profits or inconueniences ensue thereof vnto the Commonweale'.

72 Grotius, The Rights of War and Peace, pp. 763-4.

73 Hobbes, Eight Bookes of the Peloponesian Warres, pp. 49, 324. For the significance of this debate to English colonialism, see David Armitage, The Ideological 
Origins of the British Empire (Cambridge, Cambridge University Press, 2000), pp. 109-14, and Malcolm, Aspects of Hobbes, p. 63. A good portrait of the type of commonplacing reader Hobbes likely expected can be found in William Sherman, 'Sir Julius Caesar's Search Engine', in Used Books: Marking Readers in Renaissance England (Philadelphia, University of Pennsylvania Press, 2007), pp. 127-48. Hobbes re-asserted Athenian 'dominion of the sea' in his English Leviathan but muted the assertion in addressing his Latin Continental audience. Compare Leviathan: with Selected Variants from the Latin Edition of 1668, ed. E. M. Curley (Indianapolis, Hackett, 1994), pp. 455 and 469.

74 Hobbes, Eight Bookes of the Peloponesian Warres, p. 4.

75 Fitzmaurice, Humanism and America, pp. 158-9.

76 Grene (ed.), The Peloponnesian War: The Complete Hobbes Translation, p. 5. See Leviathan, Chapter 13, for a similar argument substituting 'the savage people in many places of America' who 'live at this day in the brutish manner', p. 187.

77 Francis Bacon, 'New Atlantis', in Francis Bacon, ed. Brian Vickers (Oxford, Oxford University Press, 1996), esp. pp. 466-7.

78 Steven Lattimore (ed.), The Peloponnesian War (Indianapolis, Hackett, 1998), p. 5.

79 Grene (ed.), The Peloponnesian War: The Complete Hobbes Translation, p. 3, my emphasis.

80 Bacon, 'New Atlantis', p. 467.

81 Grene also notes this omission: Grene (ed.), The Peloponnesian War: The Complete Hobbes Translation, p. 3.

82 Hobbes, Leviathan, p. 186.

83 Hobbes, Eight Bookes of the Peloponesian Warres, p. 4.

84 Ibid., p. 4. The reader of a heavily annotated copy now in the Huntington Library underlined this passage in the text and associated it with Anacreon's lyric on the grasshopper, the 'Epicurean Animal' (in Cowley's Interregnum translation). I am grateful to Dr Stephen Tabor of the Huntington Library for this information.

85 Hugh De Quehen (ed.), Lucy Hutchinson's Translation of Lucretius, De Rerum Natura (London, Duckworth, 1996), lines 840-7. Dryden's later translation is briefer though it substitutes the more generic 'insects' for 'grasshoppers': 'As even now, our tender Insects strive / To break their bags, get forth, and eat, and live. / Next Beasts, and thoughtful Man receiv'd their Birth.'

86 Grene (ed.), The Peloponnesian War: The Complete Hobbes Translation, p. 4.

87 Peter Harrison, "Fill the Earth and Subdue It": Biblical Warrants for Colonization in Seventeenth Century England', Journal of Religious History, 29:1 (2005), 3-24; Richard Tuck, 'The Making and Unmaking of Boundaries from the Natural Law Perspective', in States, Nations, and Borders: The Ethics of Making Boundaries, ed. Allen E. Buchanan and Margaret Moore (Cambridge, Cambridge University Press, 2003), pp. $143-70$ (p. 156).

88 Thomas Hobbes, Leviathan, p. 387; Tuck, Rights of War and Peace, p. 138.

89 [Dudley Digges], A True Relation of the Vniust, Cruell, and Barbarous Proceedings against the English at Amboyna in the East-Indies, by the Neatherlandish Governour and Councel There, Facsimile ed. (1624; Amsterdam, 1971), p. 10.

90 Martine Julia Van Ittersum, “"Three Moneths Observations of the Low Countreys, Especially Holland": Owen Felltham and Anglo-Dutch Relations in the Seventeenth Century', LIAS: Sources and Documents Relating to the Early Modern History of Ideas, 27:1-2 (2000), 95-160, 161-96 (p. 116 n. 53); Karen Chancey, 'The 
Amboyna Massacre in English Politics, 1624-1632', Albion, 30 (1998), 583-98.

91 Hobbes, Eight Bookes of the Peloponnesian Warre (1629), pp. 162, 429.

92 Hobbes, On the Citizen, p. 54; Malcolm, Aspects of Hobbes, p. 438.

93 Hobbes, Eight Bookes of the Peloponnesian Warre (1629), p. 173, The Peloponnesian War, p. 187.

94 Hobbes, The Peloponnesian War, p. 189, Eight Bookes of the Peloponnesian Warre (1629), p. 175.

95 Grene (ed.), The Peloponnesian War: The Complete Hobbes Translation, p. 322, Hobbes, Eight Bookes of the Peloponesian Warres, p. 300.

96 Thomas Hobbes, Leviathan, pp. 184-5, 218.

97 Degory Wheare, The Method and Order of Reading Both Civil and Ecclesiastical Histories in Which the Most Excellent Historians Are Reduced into the Order in Which They Are Successively to Be Read, and the Judgments of Learned Men Concerning Each of Them, Subjoin'd, trans. Edmund Bohun (London, M. Flesher for Charles Brome, 1685), p. 24.

98 For some brief comments about the imperial connotations of the Bacon frontispiece, see Margery Corbett and R. W. Lightbown, The Comely Frontispiece: The Emblematic Title-Page in England, 1550-1660 (London, Routledge \& Kegan Paul, 1979), pp. 185-6. Cecil would also engrave the title page for Grotius's anonymously translated True Religion Explained and Defended (1632), a work some claimed was written originally to guide Dutch sailors in converting the Indians: Hugo Grotius, Christs Passion.: A Tragedy. With Annotations, trans. George Sandys, STC 12397.5 ed. (London, John Legat, 1640), sig. [A3]v.

99 This paragraph is indebted to Ellison, George Sandys: Travel, Colonialism and Tolerance in the Seventeenth Century, pp. 101-60. Patricia Springborg links Sandys's Ovid with both the Virginia Company and Hobbes's Thucydides in 'Leviathan, Mythic History, and National Historiography', in The Historical Imagination in Early Modern Britain: History, Rhetoric, and Fiction, 1500-1800, ed. Donald R. Kelley and David Harris Sacks (Cambridge, Woodrow Wilson Center Press and Cambridge University Press, 1997), pp. 267-70.

100 Hugo Grotius, The Free Sea, trans. Richard Hakluyt, ed. David Armitage (Indianapolis, IN, Liberty Fund, 2004), pp. 25, 93; Hobbes, Old Catalogue, fol. 119.

101 Richard Beale Davis, George Sandys, Poet-Adventurer: A Study in AngloAmerican Culture in the Seventeenth Century (New York, Columbia University Press, 1955), p. 199; Thomas Rymer, Foedera, 20 vols (London, A. \& J. Churchill, 1726), XVIII, 676; Arnold Hunt, 'Book Trade Patents, 1603-1640', in The Book Trade and Its Customers, 1450-1900: Historical Essays for Robin Myers, ed. Arnold Hunt, Giles Mandelbrote, and Alison Shell (Winchester, Oak Knoll Press, 1997), pp. 27-54.

102 On Grimestone, see F. J. Levy, Tudor Historical Thought (San Marino, CA, Huntington Library, 1967), pp. 209-10.

103 For a brief discussion of the title page, see Antony Griffiths and Robert A. Gerard, The Print in Stuart Britain, 1603-1689 (London, British Museum Press for the Trustees of the British Museum, 1998), pp. 163-4.

104 Thomas Duffus Hardy, Syllabus, in English, of the Documents Relating to England and Other Kingdoms Contained in the Collection Known as 'Rymer's Foedera' (London, 1869); Thomas Farnaby, 'To My Worthy and Learned Friend, Philemon Holland, Doctor of Physicke, on His Translations', in Cyrupaedia: The 
Institution and Life of Cyrus, King of Persians. Tr. By P. Holland (London, J[ohn] L[egate] for R[obert] Allot, 1632).

105 Thomas Heywood, 'Of Doctor Philemon Holland', in Cyrupaedia.

106 For assistance on this article, I am grateful to Sharon Achinstein, Kinch Hoekstra, Fritz Levy, Noel Malcolm, David Norbrook, Dan Shore, and the editors and staff of The Seventeen Century, especially Richard Maber. Errors, of course, are my own.

\section{Address for Correspondence}

Dr Christopher N. Warren, Society of Fellows, The University of Chicago, GatesBlake Hall, Room 408, 5845 S. Ellis Ave., Chicago, IL 60637, USA, email: cnwarren@ uchicago.edu 